SIMPÓSIO DOS PROFISSIONAIS DA UNICAMP

\section{DIMINUIÇÃO DOS IMPRESSOS PARA INSCRIÇÃO NOS CONCURSOS PARA PROVIMENTO DE CARGO DE PROFESSOR DOUTOR NA FACULDADE DE CIÊNCIAS MÉDICAS}

THIAGO SANCASSANI, CAIO CÉSAR NASCIMENTO MOTA, REGINA JOYCE FRONTELLI SANTOS DUARTE

FCM - FACULDADE DE CIENCIAS MEDICAS;DIRADM - DIRETORIA DE APOIO ADMINISTRATIVO;AP - SECAO DE ADMINISTRACAO DE PESSOAL; thisanca@unicamp.br

\section{Introdução:}

DOI: $10.20396 /$ sinteses.v0i7.10119 públicos. Esse crescimento onera os cofres da Universidade, pois ocorrem diversas despesas com o deslocamento dos profissionais que compõem as Comissões Julgadoras que avaliarão os candidatos inscritos. Esse trabalho tem como objetivo diminuir os custos para a Universidade, bem como para os candidatos que se submetem aos seus concursos. A Universidade tem alto custo com o envio de materiais dos candidatos, via Correios, para os membros das bancas. Já os candidatos têm alto custo para a confecção e impressão de seus memoriais, documento obrigatório para inscrição.

\title{
Metodologia:
}

O trabalho originou-se através da Delib CONSU-A-2/2014 que delegou para as Congregações das Unidades deliberarem sobre os requisitos e procedimentos para realização dos concursos públicos da carreira docente. A CCD ? Comissão de Corpo Docente/FCM discutiu sobre a matéria e enviou a proposta para a Congregação. Em 03/06/2016 foi aprovada a Delib. № 279/2016, a qual normatiza como se procederá a inscrição dos candidatos nos concursos da FCM.

\section{Resultados}

Com a implantação da Deliberação da Congregação/FCM no 279/2016, logo em seguida, mudou-se o edital de abertura de inscrições aos concursos públicos docentes. Passamos a receber apenas 1 via do memorial impresso e 1 via em formato digital (pdf) dos candidatos ao invés de 10 vias impressas. Com essa redução de papel impresso foi possível otimizar o espaço que temos em nossos armários para acondicionamento de documentos. Com este projeto houve uma redução anual de $R \$ 4.246,00$ para a $F C M$ pois reduzimos praticamente a zero as despesas com os Correios geradas para envio, via SEDEX, dos materiais dos candidatos à Comissão Julgadora. Hoje esse gasto não é mais necessário, pois toda documentação dos candidatos é enviada aos membros das Comissões Julgadoras via e-mail. Além de ser mais ágil, o custo é zero. Também foi

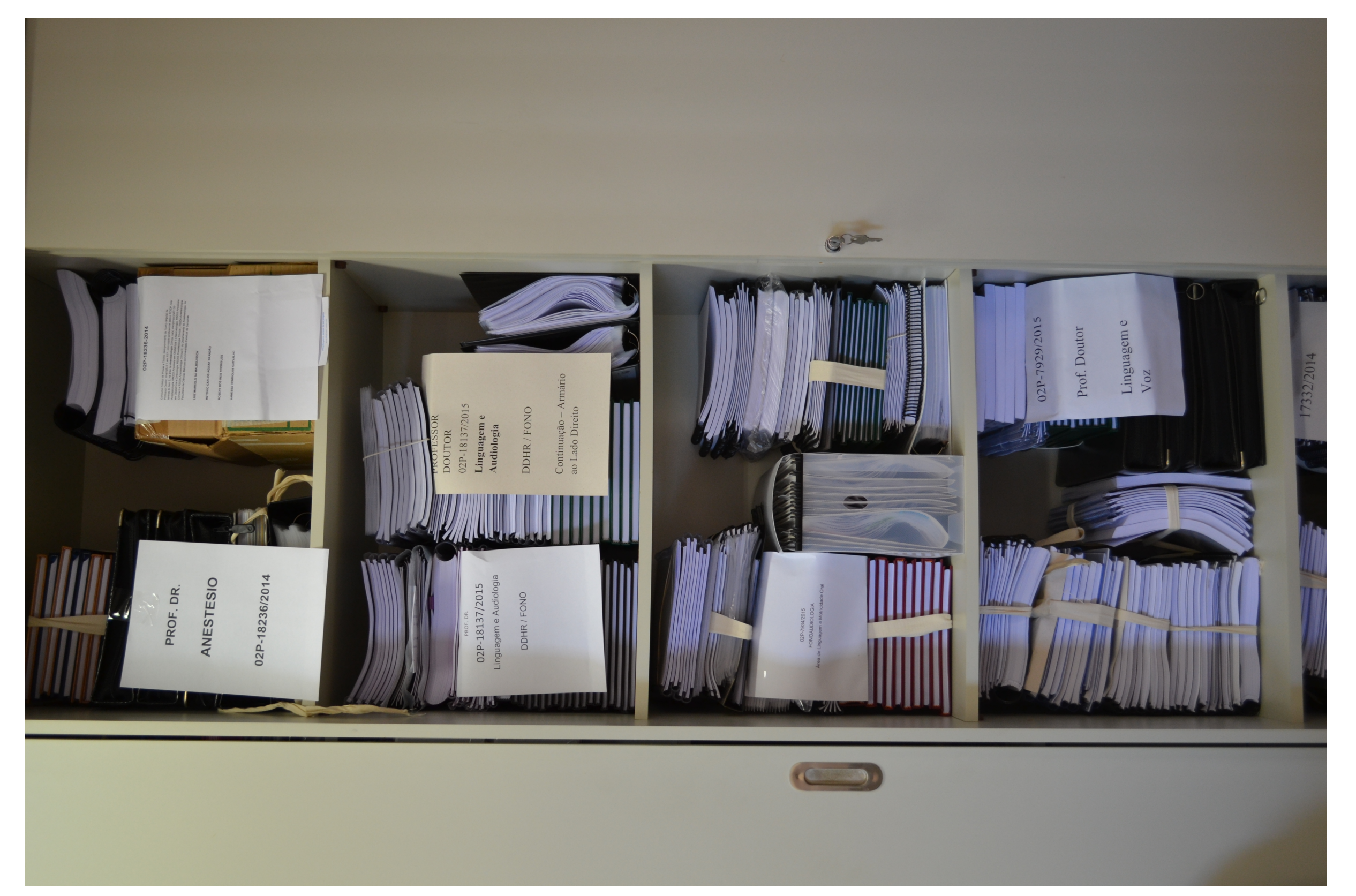

Legenda: Armários Antes possível reduzir os gastos dos candidatos que dispendiam de muito recurso financeiro com a impressão das 10 vias de memorial exigidas pelo antigo edital. E por fim, mas não menos importante, conseguimos contribuir significativamente para a preservação do meio ambiente e sua sustentabilidade. Ao utilizarmos o artifício do memorial no formato digital, consumimos menos papel e consequentemente preservamos mais árvores.

\section{Considerações finais:}

O projeto beneficiou candidatos, Comissão Julgadora, Unidade e os funcionários da FCM, totalizando até o momento 27 concursos realizados. Internamente diminuiu o material recebido e reduziu os gastos com Correios. Externamente beneficiou os candidatos que não terão mais o gasto com a impressão dos memoriais. Beneficiou também as Bancas, que recebem os materiais dos candidatos em questão de segundos e podem consultá-los de qualquer lugar. Esta melhoria pode ser implantada em toda Universidade. 